\title{
LANDASAN HUKUM ISLAM TERHADAP PRAKTIK MUZARA'AH DAN KENDALANYA PADA MASYARAKAT DI DESA TUMBUH MULIA KECAMATAN SURALAGA KABUPATEN LOMBOK TIMUR
}

\author{
Rabiatul Adawiyah \\ IAI Hamzanwadi NW Lombok Timur \\ Email: rabiatuladawiyah30@yahoo.com
}

\begin{abstract}
Abstrak
Tujuan dalam penelitian ini untuk mengetahui bagaimana Landasan Hukum Islam Terhadap Praktik Muzara'ah Dan Kendalanya Pada Masyarakat Di Desa Tumbuh Mulia. Jenis penelitian ini menggunakan penelitian lapangan (field research) yang bersifat studi kasus (case study), dengan lokasi di Dasan Tumbu, Desa Tumbuh Mulia Kecamatan Suralaga kabupaten Lombok Timur. Hasil penelitian ini menunjukkan bahwa praktik muzara'ah telah banyak dilaksanakan pada Masyarakat Desa Tumbuh Mulia, baik dari kalangan pengusaha, pegawai, pedagang, bahkan para pemilik sawah yang luas memberikan kesempatan kepada orang lain untuk memamfaatkan tanahnya. Pelaksanaan muzara'ah yang berkembang dimasyarakat sudah sesuai dengan aturan dan tujuan yang ingin dicapai besama. Akan tetapi tidak sedikit dari praktik muzara'ah tersebut hanya memperhatikan aturan tetapi tidak melihat tujuan bersama. Bahkan kepentingan pribadi masing-masing yang didahulukan dari kepentingan bersama.
\end{abstract}

Kata kunci pada skripsi ini adalah ; Hukum Islam, Praktik Muzara'ah, Masyarakat.

\begin{abstract}
The purpose of this study is to find out how the foundation of Islamic law on the practice of muzara'ah and its constraints on the community in the village of Growing Mulia. This type of research uses field research which is a case study, with a location in Dasan Tumbu, Growing Mulia Village, Suralaga District, East Lombok Regency. The results of this study indicate that the practice of muzara'ah has been widely carried out in the Growing Mulia Village Community, both from businessmen, employees, traders, and even owners of large rice fields providing opportunities for others to take advantage of their land. The implementation of muzara'ah that develops in the community is in accordance with the rules and goals to be achieved together. However, not a few of these muzara'ah practices only pay attention to the rules but do not see the common goal. Even the personal interests of each take precedence over the common interests.
\end{abstract}

The keywords in this thesis are; Islamic Law, Muzara'ah Practice, Society. 


\section{Vol. 12, No. 2, Juli 2021}

\section{PENDAHULUAN}

Salah satu syariat dalam ajaran Islam dalam bidang mu'amalah yang tujuannya semata-mata untuk memperoleh kemaslahatan di dunia adalah Muzara'ah, yakni seseorang memberikan tanahnya kepada orang lain untuk ditanami dengan upah bagian tertentu dari hasil tanah tersebut. (misalnya sepertiganya atau separuhnya). Muzara'ah, merupakan kerja sama yang sangat penting dalam kehidupan bermasyarakat, di dalam pelaksanaannya dituntut adanya keinginan untuk saling membantu antara satu sama lain. Pemilik tanah yang memiliki kelebihan berupa sawah memberikan kesempatan kepada seseorang yang mampu untuk mengolah tanahnya. Sehingga tanah tersebut dapat memberi mamfaat dan petani juga bisa memenuhi kebutuhan keluarga dengan keahliannya menggarap sawah.

Suatu hal yang sangat betul-betul di sayangkan, apabila warisan islam yang sudah berurat-berakar, tentang ilmu pengetahuan pada umumnya dan permasalahan kerja sama dalam pertanian (Muzara'ah) pada khususnya dilupakan begitu saja. Yang apabila tidak dapat di laksanakan dengan baik dalam kehidupan bermasyarakat maka akan terjadi kesenjangan antara lapisan masyarakat yang satu dengan yang. Masing-masing memikirkan kehidupan pribadi semata, tidak memperhatikan masyarakat sekelilingnya yang membutuhkan bantuannya. Oleh karena itu, melihat fenomena yang ada dan berkembang dalam masyarakat, penelitian ini sangat memerlukan banyak kajian yang mendalam tentang muzara'ah.

Dengan analisa ini dapat kita jadikan sebagai penopang yang akurat dan membawa kita kepada suatu pengetahuan dan adanya jalinan ta'awun. Dan dijadikan sebagai sistem yang diteladankan oleh Rasulullah saw merupakan salah satu dimensi penting dari sekian dimensi kelebihan yang dipancarkan oleh islam sebagai agama yang lurus.

Tata cara pelaksanaan muzara'ah dalam Islam telah diatur dengan sebaikbaiknya. Al-qur'an, Hadits serta Ijma' Qiyas para Ulama menjelaskan dan merinci secara detail hukum-hukum yang berkaitan dengan hak pekerja tanpa mengabaikan hak pemilik sawah. Pembagian masing-masing pekerja maupun pemilik sawah berdasarkan kesepakatan untuk kesejahteraan bersama antara kedua belah pihak. Pemilik sawah tidak boleh sewenangnya menentukan bagian dari hasil panen yang diperoleh, begitu pula dengan pekerja, bukan berarti karna dia yang telah mengharap sawah tersebut dia lebih berhak menentukan bagian yang dia pantas terima dan yang seharusnya diterima 


\section{Vol. 12, No. 2, Juli 2021}

oleh pemilik sawah.

\section{METODE PENELITIAN}

Jenis penelitian ini adalah penelitian lapangan (field research) yang bersifat studi kasus (case study), dengan lokasi di Dasan tumbu, Desa Tumbuh Mulia Kecamatan Suralaga kabupaten Lombok Timur. Sumber Data: a). Responden, yaitu para pemilik sawah dan penggarap sawah yang telah melakukan penyimpangan di dalam melakukan pelaksanaan muzaraah. b). Informan, yakni kepala desa dan tokoh masyarakat setempat yang dapat memberikan informasi dalam penelitian ini. c).Dokumen, yaitu berkas-berkas atau catatan yang berhubungan dengan obyek yang akan di teliti. Tehnik pengumpulan data menggukan observasi, wawancara dan dokumentasi.

\section{HASIL PENELITIAN}

\section{Analisis Praktik Muzara'ah Pada Masyarakat Desa Tumbuh Mulia}

Setelah memperhatikan uraian-uraian pada bagian sebelumnya, serta hasil observasi dan dokumentasi dilapangan, dapat penulis analisis bahwa sebagian besar para pekerja pada peraktik muzara'ah di Desa Tumbuh Mulia tidak melaksanakan tugas dan kewajibannya dengan baik, berbagai keluhan yang disampaikan oleh kesadaran para pekerja atas apa yang diamanatkan padanya.
Kasus pertama, Pada kasus pertama pekerja lebih mengutamakan kepentingan pribadinya dari kewajiban sebagai pekerja pada kerja sama muzara'ah yang telah disepakati. Akibatnya pemilik sawah merasa dirugikan oleh pekerja, sementara tujuan pelaksanaan muzara'ah adalah untuk memperoleh kemaslahatan bersama. Kasus kedua, Pada kasus kedua, pekerja bertindak sewenangnya. Pekerja tidak memusyawarahkan apa yang sabaiknya ditanam pada lahan tersebut. Pekerja meminta modal sejak pemelian bibit sampai panennya. Dengan demikian, kerja sama antara pemilik sawah dan pekerja tidak berdasarkan kesepakatan bersama. Kasus ketiga, Kasus ketiga mencerminkan pelaksanaan muzara'ah yang sesuai dengan tujuan bersama. Pekerja memperoleh kemaslahatan dengan hasil panen sawah dan pemilik sawah merasa puas dengan kinerja pekerjanya. Dengan demikian pelaksanaan muzara'ah telah dipraktikkan dengan sebaikbaiknya.

\section{Analisis Kendala-kendala dalam \\ Pelaksanaan Muzara'ah}

Analisis peneliti pada kendala dalam pelaksanaan muzara'ah adalah kurangnya jalinan shilaturrahmi yang baik antara pemilik 


\section{Vol. 12, No. 2, Juli 2021}

sawah dengan pekerja. Pemilik sawah yang tidak mengawasi kinerja pekerja mengakibatkan pekerja bertindak diluar dari kesepakatan bersama. Disamping itu, pekerja yang diamanatkan memamfaatkan sawah tidak mengkomunikasikan dengan baik apa yang terjadi dengan sawah dan tanamannya. Tatkala hasil tanaman bagus pekerja berusaha menutupinya, sementara apabila hasil panen sedikit maka secepat mungkin pekerja melaporkannya kepada pemilik sawah.

\section{Kesimpulan}

Praktik muzara'ah telah banyak dilaksanakan pada Masyarakat Desa Tumbuh Mulia. Pelaksanaan muzara'ah yang berkembang dimasyarakat sudah sesuai dengan aturan dan tujuan yang ingin dicapai besama. Ada beberapa prosedur pelaksanaan Muzara'ah pada masyarakat: a). Tanah dan bibit dari pemilik tanah, sedangkan kerja dan alat dari petani, sehingga yang menjadi objek adalah jasa petani dengan pembagian hasil $50 \%-50 \%$. b).Pemilik tanah hanya menyediakan tanah, sedangkan petani menyediakan bibit, alat petani, sehingga yang menjadi obyek al-muzara'ah adalah jasa petani, dengan pembagian 60\%-40\%.

Dari beberapa sample yang penulis temukan di Masyarakat Suralaga, terdapat beberapa faktor sebagai alasan utama masyarakat dalam memperaktikkan muzara'ah, antara lain sebagai berikut : a). Hubungan keluarga. b). Pemahaman dan kesempatan yang tidak memadai untuk bertani. c).Lahan yang luas tidak mampu dikerjakan oleh pemilik sawah serta lahan yang tidak dimiliki oleh petani untuk digarap. Adapun kendala-kendala yang dihadapi oleh Masyarakat Tumbuh Mulia pada praktik muzara'ah berdasarkan hasil penelitian antara lain :a). Kurangnya kesadaran para pekerja akan tugas dan tanggung jawabnya. b).Hilangnya kepercayaan pemilik sawah terhadap pekerja. c).Miss komunikasi antara pemilik sawah dan pekerja.

\section{DAFTAR PUSTAKA}

Al-Jazri Abdurrahman, 1969, kitab Al-fiqhi ala mazahibil arba'ah, Kairo Mesir: At-Taufiqiyah.

Departemen Agama RI, 1994, Al-Qur'an dan terjemahannya, Yayasan Penyelenggara Penterjemahan

AlHaroen, Nasroen, 2000, Fiqih Muamalah, Jakarta: Gaya Media Pratama Haroen, Fiqh Mu'amalah, Cetetakan Ke-1, Gaya Media Pratama, Jakarta, 2000, hal. 275

H. Sulaeman Rasyid, 1994, Fiqih Islam, Bandung: PT. Sinar Baru Algensindo, http://psikonseling.blogspot.com/2010/02 /pengertian- muzara'ah.html Muhammad, 2001, Teknik Perhitungan Bagi Hasil, Yogyakarta : UII Press. 
Qordowi, Yusuf, 2000. Norma Etika Bisnis Islam, Jakarta: Gema Insani Pers:,

Sayyid, Sabiq, 1976, Fiqih Sunnah 3 Jilid AlQorikhah: Surabaya: Dar Assaqopatu Al-Islamiyah, jilid 3,

Zainuddin. 1999, Al-Islam (Muamalah dan Akhlak. Cet I. Bandung: CV Pustaka Setia 